\title{
Uji Efektivitas Ekstrak Daun Sirsak terhadap Jamur Microsporum gypseum Penyebab Dermatitis Kompleks Pada Anjing
}

\section{(EFFECTIVENESS OF SOURSOP LEAF EXTRACT To Microsporum gypseum CAUSE DERMATITIS COMPLEX ON DOG)}

\author{
Angelina Serlin ${ }^{1}$, I Nyoman Suartha ${ }^{2 *}$, Aida Louise Tenden Rompis ${ }^{3}$ \\ ${ }^{1}$ Dinas Peternakan Kabupaten Manggarai, Nusa Tenggara Timur; \\ ${ }^{2}$ Laboratorium Ilmu Penyakit Dalam, Fakultas Kedokteran Hewan, Universitas Udayana, Jln. \\ PB Sudirman, Denpasar Bali; ${ }^{3}$ Laboratorium Bakteriologi dan Mikologi Veteriner, Fakultas \\ Kedokteran Hewan Universitas Udayana, Jln. PB Sudirman, Denpasar Bali. \\ *Email: nyoman_suartha@unud.ac.id
}

\begin{abstract}
Abstrak
Daun sirsak (Annona muricata L.) mengandung senyawa aktif seperti flavonoid, saponin dan tanin yang berperan sebagai antijamur. Penelitian ini bertujuan untuk mengetahui kemampuan ekstrak daun sirsak dalam menghambat pertumbuhan jamur Microsporum gypseum penyebab dermatitis kompleks pada anjing. Kemampuan ekstrak daun sirsak dalam menghambat pertumbuhan jamur $M$. gypseum diuji dengan modifikasi metode difusi lempeng agar (Kirby Bauer) dengan teknik sumuran. Rancangan penelitian yang digunakan adalah rancangan acak lengkap (RAL) dengan 4 perlakuan yaitu ekstrak daun sirsak konsentrasi $0 \%, 5 \%, 10 \%$, dan 25\%, dengan ulangan 4 kali dan larutan ketokonazol sebagai kontrol positif. Hasil penelitian menunjukan bahwa rataan besar zona hambat yang terbentuk pada konsentrasi $5 \%, 10 \%$, dan $25 \%$ secara berturut- turut yaitu 2,50 mm $\pm 0,00,3,55$ $\mathrm{mm} \pm 0,00$, dan $5,00 \mathrm{~mm} \pm 0,58$. Secara statistik ada perbedaan yang sangat nyata $(\mathrm{p}<0,01)$ antara rataan besar zona hambat masing-masing perlakuan. Disimpulkan ekstrak daun sirsak mampu menghambat pertumbuhan jamur M. gypseum penyebab dermatitis kompleks pada anjing.
\end{abstract}

Kata kunci: Microsporum gypseum; dermatitis kompleks; daun sirsak (Annona muricata L.)

\begin{abstract}
Soursop leaf (Annona muricata L) contains active compounds such as flavonoids, saponins, and tannins that act as antifungals. This study aims to determine the ability of soursop leaf extract in inhibiting the growth of Microsporum gypseum, which causing dermatitis complex in dogs. The ability of soursop leaf extract to inhibit the growth of M. gypseum was tested using the agar plate diffusion method (Kirby Bauer) with slight modification. Complete randomized design (RAL) with four treatment, i.e., soursop leaf extract $0 \%, 5 \%, 10 \%$, and $25 \%$, with four replication and ketoconazole as a positive control was used in the study. The results showed that the inhibitory zones formed at concentrations of $5 \%, 10 \%$, and $25 \%$ were $2.50 \mathrm{~mm} \pm 0.00,3.55 \mathrm{~mm} \pm 0.00$, and $5.00 \mathrm{~mm}$ $\pm 0,58$, respectively. Statistically, there was a highly significant difference $(p<0.01)$ between the average inhibitory zone of each treatment. Conclusion based on the test effectiveness of the soursop leaf extract is able to inhibit the growth of M. gypseum, which causing dermatitis complex in dogs.
\end{abstract}

Keywords: Microsporum gypseum; complex dermatitis; soursop leaf (Annona muricata L.)

\section{PENDAHULUAN}

Kulit merupakan salah satu organ tubuh terluar yang rentan terhadap penyakit, khususnya infeksi jamur. Infeksi jamur adalah salah satu agen penyebab dermatitis kompleks pada anjing. Selain jamur, agen penyebab dermatitis adalah parasit (caplak dan tungau), bakteri, virus, gangguan hormonal, alergi dan hipersensitivitas. Kombinasi dari agen infeksi ini menimbulkan dermatitis kompleks dengan gejala yang kompleks seperti kegatalan, kerontokan rambut, kemerahan kulit, nodul-nodul bernanah, 
dan bau yang tidak sedap (Madleau dan Hlinica, 2006). Kulit yang terserang akan basah dan berair, dan ada eksudat yang mengering pada rambut. Hal itu dapat memicu bakteri flora normal kulit seperti bakteri Staphylococcus. intermedius menjadi patogen (Futagawa-Saito et al., 2006). Kasus dermatitis pada hewan kesayangan seperti anjing dan kucing dilaporkan sangat tinggi diberbagai daerah di Indonesia seperti Yogyakarta dan dilaporkan kasus penyakit kulit mendominasi kasus dari pasien-pasien yang berobat ke rumah sakit hewan (Widyastuti et al., 2012; Tjahajati et al., 2013; Tjahajati, 2014).

Kasus dermatitis pada anjing juga dilaporkan di beberapa negara, seperti di kota Gwangjo, Korea ditemukan bahwa 45,6 \% (47/103) anjing jalanan menderita penyakit kulit disebabkan oleh infeksi tunggal maupun lebih dari satu agen penyakit (multiple infestation) (Chee et al, 2008). Kejadian dermatosis pada anjing jalanan di Bali ditemukan sebanyak 37,9\% baik yang disebabkan oleh satu agen infeksi ataupun infeksi dari beberapa agen secara bersamaan (Wirayana et al., 2014). Salah satu agen jamur yang ditemukan sebagai penyebab dermatitis kompleks pada anjing adalah dari golongan dermatofita yakni Microsporum gypseum. Jamur M. gypseum memiliki sifat geofilik dengan distribusi di seluruh dunia yang sering menginfeksi kulit dan rambut hewan dan manusia (Jawetz et al., 2001). Golongan jamur ini dapat mencerna keratin kulit (keratinofilik) yang dapat menyerang lapisan-lapisan kulit mulai dari stratum korneum sampai dengan stratum basalis.

Terapi anti jamur selama ini menggunakan obat kimia, namun penggunaan obat-obat seperti amfoterisin, nistatin, ketokonazol, dan griseofulvin harganya relatif mahal (Rintiswati et al., 2004; Saifudin, 2011). Berkaitan dengan masalah tersebut, dapat dipilih alternatif lain dengan memanfaatkan obat herbal. Penggunaan obat herbal secara umum dinilai lebih aman daripada penggunaan obat kimia.

Salah satu bahan alam yang sudah lama dimanfaatkan oleh masyarakat sebagai obat herbal adalah tanaman sirsak (Annona muricata L.). Tanaman ini memiliki aktivitas farmakologi utama termasuk sitotoksik, antileishmanial, penyembuhan luka, antimikroba (Patel, 2016). Diketahui daun sirsak mengandung senyawa aktif flavonoid, saponin dan tanin berperan sebagai antifungal (Masloman et al., 2016), maka penelitian ini dilakukan bertujuan untuk mengetahui kemampuan ekstrak daun sirsak dalam menghambat pertumbuhan jamur $M$. gypseum penyebab dermatitis kompleks pada anjing.

\section{METODE PENELITIAN}

Penelitian ini menggunakan rancangan acak lengkap (RAL) dengan 5 perlakuan yaitu ekstrak daun sirsak konsentrasi $0 \%$ (sebagai kontrol negatif), 5\%, 10\%, dan 25\%), larutan ketokonazol sebagai kontrol positif, setiap perlakuan diulang sebanyak 4 kali. Isolat jamur yang digunakan adalah isolat jamur $M$. gypseum yang telah diisolasi di Laboratorium Mikrobiologi Fakultas Kedokteran Hewan Universitas Udayana dari anjing yang mengalami dermatitis kompleks. Data yang diperoleh dianalisis dengan sidik ragam Univariate, uji BNT, dan analisis regresi. Analisis dilakukan dengan menggunakan program SPSS 17 for Window.

\section{Pembuatan ekstrak daun sirsak}

Ekstraksi daun sirsak dikerjakan di laboratorium terpadu (Lab Marine) Pascasarjana Universitas Udayana. Daun sirsak dipotong dengan ukuran $0,5 \mathrm{~cm}$, dikeringkan dengan cara dianginanginkan, selanjutnya daun sirsak yang sudah kering diblender sehingga menjadi serbuk halus. Serbuk daun sirsak direndam dengan methanol selama 24 jam untuk proses ekstraksi. Hasil ekstraksi disaring dengan kertas saring GF227, untuk memisahkan bagian substrat dan filtrat. Filtrat dikeringkan dengan evaporator 
sehingga diperoleh ekstrak daun sirsak yang siap digunakan untuk penelitian.

\section{Pembuatan media Sabaroud Dextrose Agar (SDA)}

Sabaroud Dextrose Agar ditimbang seberat 65gram dan dicampur dengan $1 \mathrm{~L}$ akuades dan ditambah $1 \%$ streptomycin, kemudian dimasukan ke dalam gelas kimia. Setelah itu, media ditutup menggunakan aluminium foil lalu disterilkan dalam autoklaf dengan temperatur $121^{\circ} \mathrm{C}$ selama $15-20$ menit, kemudian masing-masing cawan petri dituangkan sebanyak $\pm 15-20 \mathrm{ml}$ SDA. Selanjutnya tunggu memadat di suhu ruangan.

\section{Pembuatan suspensi jamur}

Pembuatan suspensi jamur uji dilakukan dengan mengambil satu osa kultur jamur $M$. gypseum pada media SDA dan dimasukan ke dalam tabung reaksi yang berisi larutan $\mathrm{NaCl} 0,9 \%$ sebanyak $3 \mathrm{ml}$, kemudian dicampur hingga homogen ditandai dengan cairan berubah menjadi keruh sesuai standar kekeruhan McFarland 0,5 yang bertujuan agar jumlah kepadatan sel jamur yang digunakan dalam penelitian ini sama pada seluruh perlakuan.

\section{Metode uji sensitivitas}

Metode yang digunakan adalah modifikasi metode difusi lempeng agar (Kirby Bauer) yang merupakan metode uji kepekaan langsung dengan teknik sumuran. Media SDA disediakan dan bagian belakang cawan petri diberi kode menggunakan spidol sesuai dengan keempat perlakuan. Suspensi jamur diinokulasikan dengan cara diambil dari sediaan kemudian diinokulasikan secara merata dan menyeluruh pada media SDA yang telah dibuat lubang-lubang atau sumuran dengan alat khusus (cork borer) atau dengan menggunakan potongan besi antena steril dengan diameter tertentu. Setelah proses inokulasi pada media SDA selesai, selanjutnya lubang atau sumuran yang telah dibuat diisi dengan ekstrak daun sirsak dengan konsentrasi yang berbeda $(5 \%, 10 \%, 25 \%)$ pada setiap lubang atau sumuran dengan volume sebanyak $0,2 \mu \mathrm{L}$, sedangkan pada lubang kontrol negatif dengan konsentrasi $0 \%$ diisi dengan tween $2 \%$ dan kontrol positifnya diisi dengan larutan ketokonazol. Kemudian cawan diinkubasikan pada suhu $37^{\circ} \mathrm{C}$ selama 24 jam dan diamati selama seminggu sampai terbentuknya zona hambatan (Masloman, 2016).

\section{Pengamatan hasil uji sensitivitas}

Pengamatan dilakukan dengan melihat adanya zona hambat pada pertumbuhan jamur $M$. gypseum yang terbentuk di daerah sekitar lubang sumuran yang telah diberi ekstrak daun sirsak pada media SDA. Terbentuknya lingkaran hijau disekitar lubang media menunjukan hasil positif dan diameter zona hambat diukur dengan satuan millimeter ( $\mathrm{mm})$ menggunakan penggaris. Kemudian diameter zona hambat tersebut dikategorikan kekuatan daya antijamur berdasarkan penggolongan Davis dan Stout (1971) dalam (Kandoli et al., 2016):

a. Diameter zona hambat diatas $20 \mathrm{~mm}$ artinya daya hambat sangat kuat,

b. Diameter zona hambat 11-20 mm artinya daya hambat kuat,

c. Diameter zona hambat 5-10 $\mathrm{mm}$ artinya daya hambat sedang,

d. Diameter zona hambat $0-4 \mathrm{~mm}$ artinya daya hambat lemah.

\section{HASIL DAN PEMBAHASAN}

Ekstrak daun sirsak mampu menghambat pertumbuhan jamur $M$. gypseum. Pada masing-masing lubang sumuran yang telah diberi perlakuan ekstrak daun sirsak dan diinkubasi selama 24 jam (Gambar 1), yang ditandai dengan adanya zona hambat dengan bentuk lingkaran hijau tanpa adanya pertumbuhan koloni jamur.

Rataan diameter zona hambat yang terbentuk karena pengaruh pemberian ekstrak daun sirsak adalah $2,75 \pm 1,90 \mathrm{~mm}$. Zona hambat merupakan lingkaran hijau 
yang terbentuk di sekitar sumuran yang tidak ditumbuhi jamur $M$. gypseum. Rerata zona hambat yang terbentuk pada konsentrasi ekstrak daun sirsak 0\%, 5\%, $10 \%$, dan $25 \%$ secara berturut-turut adalah $0,00 \pm 0,00 \mathrm{~mm}, \quad 2,50 \pm 0,00 \mathrm{~mm}$, $3,55 \pm 0,00 \mathrm{~mm}, 5,00 \pm 0,58 \mathrm{~mm}$ (Tabel 1).

Berdasarkan hasil analisis ragam, dinyatakan bahwa konsentrasi ekstrak daun sirsak memberikan pengaruh yang sangat nyata $(\mathrm{P}<0,01) \quad$ terhadap pertumbuhan jamur $M$. gypseum. Hubungan antara pengaruh konsentrasi ekstrak daun sirsak dengan masing-masing zona hambat yang terbentuk didapatkan korelasi dengan persamaan $\mathrm{Y}=$ $1,954+0,700 \mathrm{~K}-0,045 \mathrm{~K}^{2}+0,001 \mathrm{~K}^{3}$ dan koefisien korelasi sebesar $r=0,991$.

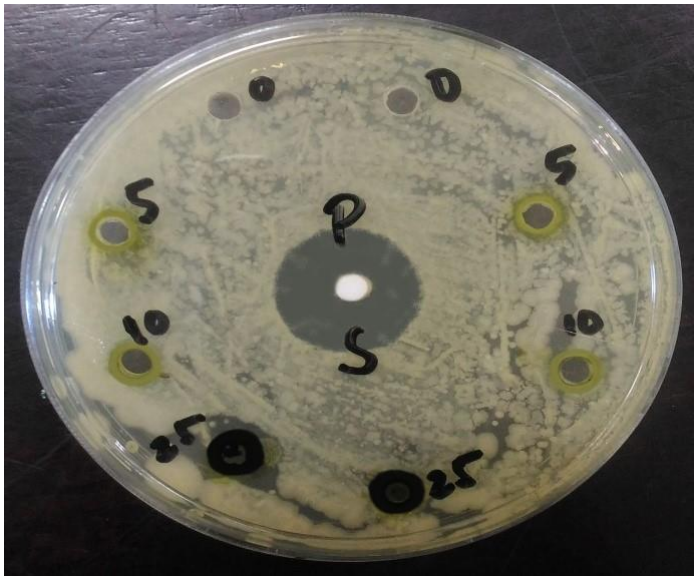

Gambar 1. Zona hambat yang terbentuk. Keterangan: PS = Kontrol positif ekstrak Sirsak; $25=$ Konsentrasi $25 \% ; 10=$ Konsentrasi $10 \%$; $5=$ Konsentrasi $5 \%$.

Tabel 1. Rataan diameter zona hambat berbagai konsentrasi ekstrak daun sirsak terhadap jamur M. gypseum.

\begin{tabular}{ccc}
\hline $\begin{array}{c}\text { Konsentrasi } \\
\text { Ekstrak Sirsak } \\
(\%)\end{array}$ & $\mathrm{N}$ & $\begin{array}{c}\text { Rataan Zona Hambat } \pm \text { Standar Deviasi } \\
(\mathrm{mm})\end{array}$ \\
\hline 0 & 4 & $0,00 \pm 0,00^{\mathrm{a}}$ \\
5 & 4 & $2,50 \pm 0,00^{\mathrm{b}}$ \\
10 & 4 & $3,50 \pm 0,00^{\mathrm{c}}$ \\
25 & 4 & $5,00 \pm 0,58^{\mathrm{d}}$ \\
\hline Total & 16 & $2,75 \pm 1,90$
\end{tabular}

Ket: Huruf yang berbeda ke arah kolom menunjukkan perbedaan besar diameter zona hambat yang sangat nyata $(\mathrm{P}<0,01)$

Zona hambat yang terbentuk disebabkan adanya zat-zat aktif yang terkandung dalam daun sirsak seperti tanin, saponin, dan flavonoid (Mardiana dan Ratnasari, 2007). Tanin berperan sebagai pertahanan tubuh, mekanisme kerja tanin yaitu bereaksi dengan protein dari larutan dan membentuk senyawa yang tidak larut. Senyawa tersebut memberikan rasa pahit atau sepat akibatnya jamur menghindari memakan makanan yang mengandung tanin karena rasanya yang pahit. Saponin bersifat surfaktan yang berbentuk polar sehingga akan memecah lemak pada membran sel yang pada akhirnya menyebabkan gangguan permeabilitas membran sel. Hal tersebut mengakibatkan proses difusi bahan atau zat-zat yang diperlukan oleh jamur dapat terganggu, akibatnya sel jamur dapat membengkak dan bahkan lisis. Sedangkan mekanisme kerja flavonoid yaitu mengganggu proses difusi makanan ke dalam sel sehingga pertumbuhan jamur terhenti atau jamur tersebut mati (Masloman, 2016). Namun tidak diketahui secara pasti zat aktif yang mana yang lebih banyak berpengaruh dalam menghambat pertumbuhan jamur M. gypseum.

Daya hambat dari ekstrak daun sirsak terhadap pertumbuhan jamur M. gypseum adalah lemah berdasarkan kategori kekuatan daya antijamur Davis dan Stout (1971) dalam (Kandoli et al., 2016) dan 
juga lebih kecil dibandingkan dengan daya hambat yang dihasilkan oleh ketokonazol yaitu sebesar 15,00 mm. Namun, dari hasil pengamatan tetap menunjukan bahwa ekstrak daun sirsak mampu menghambat pertumbuhan jamur M. gypseum meskipun zona hambat yang dihasilkan kecil. Kecilnya zona hambat dapat dipengaruhi oleh metode ekstraksi daun sirsak yang baru tahap pertama sehingga perlu dilakukan penelitian lanjutan dengan menggunakan pemurnian zat aktif lebih lanjut dengan fraksinasi dan kromatografi.

Korelasi hubungan antara konsentrasi dan daya hambat dapat ditunjukkan dengan persamaan $\mathrm{Y}=-1,954+0,700 \mathrm{~K}$ $0,045 \mathrm{~K}^{2}+0,001 \mathrm{~K}^{3}, \quad$ dan koefisien kolerasinya adalah $\mathrm{r}=0,991$. Hal ini menunjukkan bahwa zona hambat yang terbentuk pada masing-masing konsentrasi ekstrak daun sirsak memiliki perbedaan. Mujim (2010) menyatakan bahwa meningkatnya konsentrasi ekstrak menyebabkan meningkatnya kandungan bahan aktif yang berfungsi sebagai antijamur sehingga kemampuannya dalam menghambat pertumbuhan suatu jamur juga semakin besar. Hal yang sama juga dilaporkan oleh Sawitri et al. (2011) yang menunjukkan adanya kecenderungan semakin tinggi konsentrasi ekstrak daun sirsak maka zona hambat yang terbentuk semakin besar.

\section{SIMPULAN DAN SARAN}

\section{Simpulan}

Ekstrak daun sirsak) mampu menghambat pertumbuhan jamur $M$. gypseum penyebab dermatitis kompleks pada anjing. Konsentrasi Ekstrak daun sirsak 25\% lebih efektif terhadap jamur $M$. gypseum penyebab dermatitis kompleks pada anjing.

\section{Saran}

Ekstrak daun sirsak perlu diujicobakan pada anjing yang mengalami dermatitis kompleks untuk melihat kemampuan ekstrak daun sirsak dalam menghambat pertumbuhan jamur M. gypseum.

\section{UCAPAN TERIMAKASIH}

Ucapan terimakasih ditujukan kepada Kementerian Ristekdikti atas bantuan dana melalui hibah penelitian Unggulan Perguruan Tinggi melalui LPPM Universitas Udayana dengan kontrak No: 486.40/UN.14.2/PNL.01.03.00/2016 dan Balai Besar Veteriner Denpasar Bali.

\section{DAFTAR PUSTAKA}

Chee JH, Kwon JK, Cho HS, Cho KO, Lee YJ, Shin SS. 2008. A survey of ectoparasite infestation in stray dogs of Gwang-ju City, Republic of Korea. Korean J. Parasitol., 46(1): 23-27.

Futagawa-Saito K, William BT, Naomi S, Tsuguaki F. 2006. Prevalence of virulence factors in Staphylococcus intermedius isolates from dogs and pigeons. BMC Vet. Res., 2(4): 1-5.

Jawetz E, Melnick JL, Adelberg EA. 2001. Mikrobiologi Kedokteran. Buku I. Widorini N, penerjemah. Jakarta (ID): Salemba Medika.

Mardiana L, Ratnasari J. 2007. Ramuan dan Khasiat Sirsak. Penebar Swadaya. Hal. 21-33.

Masloman AP, Pangemanan DHC, Anindita PS. 2016. Uji daya hambat ekstrak daun sirsak (Annona muricata L.) terhadap pertumbuhan jamur Candida albicans. J. Ilmiah Farm., 5(4): 61-68.

Medleau L, Hnilica KA. 2006. Small Animal Dermatology. A Colour Atlas and Therapheutic. Second Edition. Saunders Elseivier. St Louis Missouri.

Mujim S. 2010. Pengaruh ekstrak rimpang jahe (Zingiber officinale Rosc.) terhadap pertumbuhan Pythium Sp. penyebab penyakit rebah kecambah mentimun secara in vitro. J. HPT Trop., 10(1): 59-63.

Patel MS, Jayvadan KP. 2016. A review on a miracle fruits of Annona muricata. J. Pharm. Phytochem., 5(1): 137-148. 
Rintiswati N, Winarsih NE, Malueka RG. 2004. Potensi antikandida ekstrak madu secara in vitro dan in vivo. Berkala Ilmu Ked., 36(4): 187-94.

Saifudin A. 2011. Standardisasi Bahan Obat Alam. Yogyakarta: Graha Imu. Pp. 1-11.

Sawitri MY, Mahatmi H, Besung INK. 2013. Daya hambat perasan daun sambiloto terhadap pertumbuhan bakteri Echerichia coli. Indonesia Med. Vet., 2(2): 142-150.

Tjahajati I. 2013. Update common parasitic disease in dog. Seminar Ilmiah Dokter Hewan. 14 Nopember 2013. Pulmann Hotel Bali.

Tjahajati I, Widiastuti TA, Erarindah E, Prayitno AD, Rifqiyanto L, Hanafi I.
2014. Macam pasien dan persentase pasien anjing dan kucing yang terinfeksi endoparasit dan ektoparasit yang ditangani di Klinik Hewan Jogja Tahun 2013-2014. Proseding Kivnas ke-13 PDHI. Palembang 23-26 Nopember 2014.

Widyastuti SK, Dewi NMS, Utama IH. 2012. Kelaianan kulit anjing jalanan pada beberapa lokasi di Bali. Buletin Vet. Udayana, 4(2): 81-86.

Wirayana IKS, Damriyasa IM, Dharmawan NS, Arnawa KAA, Dianiyanti K, Harumna D. 2014. Kejadian dermatosis yang tinggi pada anjing jalanan di Bali. J. Vet., 15(2): 217-220. 